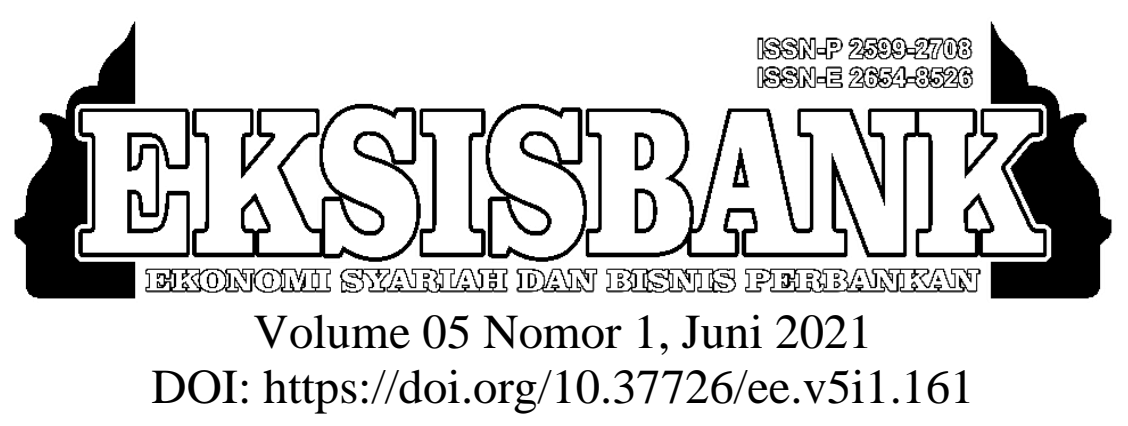

\title{
Pengaruh Product, Price, Place Dan Promotion Terhadap Keputusan Nasabah Simpanan Fleximax Di PT. Bank Panin Dubai Syariah KCU Bandung
}

\author{
Gina Sakinah ${ }^{1}$, Ade Ponirah ${ }^{2}$, Intan Nurjanah ${ }^{3}$ \\ ${ }^{1}$ Manajemen Keuangan Syariah, UIN Sunan Gunung Djati Bandung \\ ${ }^{1}$ ginasakinah1004@gmail.com \\ ${ }^{2}$ Magister Ekonomi Syariah, UIN Sunan Gunung Djati Bandung \\ 2adeponirah@gmail.com \\ ${ }^{3}$ Perbankan Syariah, Universitas Al-Ma'soem \\ 3intannurjanah648@gmail.com
}

\begin{abstract}
ABSTRAK
Perusahaan dituntut untuk mampu bersaing dalam dunia pemasaran. Karena jantung perusahaan terletak pada dunia pemasaran. Agar operasional perusahaan berjalan lacar maka proses pemasaran harus berjalan dengan baik. Ada beberapa faktor yang harus diperhatikan oleh tim manajemen dalam menentukan strategi pemasaran yang dikenal dengan bauran pemasaran. Pada artikel ini akan menganalisis pengaruh Product, Price, Place dan Promotion terhadap Keputusan Nasabah Tabungan Fleximax Bank Panin Dubai Syariah KCU Bandung. Product merupakan segala sesuatu yang siap dipasarkan oleh produsen untuk mendapatkan perhatian, diminta sampai dengan dibeli untuk pemenuhan kebutuhan. Price ialah nilai suatu barang atau jasa yang diukur dengan uang guna mendapatkan barang atau manfaatnya. Place merupakan lokasi yang bersifat tetap atau keberadaan sebuah perusahaan. Promotion ialah komunikasi penjualan yang bersifat persuasive mempengaruhi konsumen agar tertarik dengan produk yang ditawarkan. Hasil penelitain menunjukkan semua variabel independen berpengaruh terhadap variabel dependen. Pertama, hasil t-test pertama, diperoleh t-test 2,232 dengan taraf signifikansi 0,029, artinya Product memapu memberikan pengaruh secara signifikan terhadap Keputusan Nasabah Simpanan Fleximax secara parsial; Kedua, hasil t-test diperoleh t-test 2,128 dengan taraf signifikansi 0,037, aryinya Price mempu memberikan pengaruh secara signifikan terhadap Keputusan Nasabah Simpanan Fleximax secara parsial; Ketiga, hasil t-test diperoleh t-test 3,346 dengan taraf signifikansi 0,001, artinya Place memapu memberikan pengaruh secara signifikan terhadap Keputusan Nasabah Simpanan Fleximax secara parsial; Keempat, hasil t-test diperoleh t-test 3,106 dengan taraf signifikansi 0,003.
\end{abstract}

EKSISBANK (Ekonomi Syariah dan Bisnis Perbankan), Volume 5, Nomor 1, Juni 2021 http://journal.sties-purwakarta.ac.id/index.php/EKSISBANK/ 
Artinya Promotion memapu memberikan pengaruh secara signifikan terhadap Keputusan Nasabah Simpanan Fleximax secara parsial. Uji Pengaruh Product, Price, Place Dan Promotion Terhadap Keputusan Nasabah secara simultan diperoleh hasil f-statitics sebesar 3,894 dengan signifikansi 0,007. Hasil ini mengandung arti bawah seluruh variabel independen mampu memberikan pengaruh signifikan terhadap keputusan nasabah karena nilai signidikan lebih kecil dari 0,05. Implikasi dalam penelitian ini pihak manajemen Bank Panin Dubai Syariah harus bisa mempertahankan dan dapat meningkatkan kembali produk-produk perbankan yang sesuai dengan kebutuhan masyarakat khususnya Simpanan Felximax mampu menjawab kebutuhan masyarakat saat ini. Dengan kemudahan dan keunggulannya. Sehingga banyak nasabah yang tertarik untuk menyimpan dananya dengan produk simpanan fleximax. Dengan memperhatikan faktor-faktor bauran pemasaran, maka hal ini dapat menunjang berjalannya perusahaan dan mampu bersaing dengan produk konvensional yang lebih dulu ada.

Kata kunci - Keputusan Nasabah, Product, Price, Place, Promotion,.

\section{ABSTRACT}

Companies are required to be able to compete in the world of marketing. Because the heart of the company lies in the world of marketing. In order for the company's operations to run smoothly, the marketing process must run well. There are several factors that must be considered by the management team in determining a marketing strategy known as the marketing mix. In this article, we will analyze the effect of Product, Price, Place and Promotion on Customer Decisions for Fleximax Savings Bank Panin Dubai Syariah KCU Bandung. Product is everything that is ready to be marketed by producers to get attention, requested until purchased to fulfill needs. Price is the value of an item or service that is measured in money to get the goods or benefits. Place is a permanent location or existence of a company. Promotion is sales communication that is persuasive in influencing consumers to be interested in the products offered. The results of the research show that all independent variables have an effect on the dependent variable. First, the results of the first t-test, obtained a t-test of 2.232 with a significance level of 0.029 , meaning that the product is able to have a significant influence on the decision of the Fleximax Savings Customer partially; Second, the results of the t-test obtained a t-test of 2.128 with a significance level of 0.037 , meaning that Price is able to give a significant influence on the decision of the Fleximax Savings Customer partially; Third, the results of the t-test obtained t-test 3.346 with a significance level of 0.001 , meaning that Place is able to have a significant influence on the decision of the Fleximax Savings Customer partially; Fourth, the t-test results obtained t-test 3.106 with a significance level of 0.003 . This means that Promotion is able to have a significant influence on the Fleximax Savings Customer Decision partially. Testing the Effect of Product, Price, Place and Promotion on Customer Decisions simultaneously obtained f-statistics results of 3.894 with a significance of 0.007 . This result means that all independent variables are able to have a significant influence on customer decisions because the significant value is less than 0.05. The implication of this research is that the management of Bank Panin Dubai Syariah must be able to maintain and be able to improve banking products that are in accordance with the needs of the community, especially Felximax Savings that is able to answer the needs of today's society. With its convenience and advantages. So that many customers are interested in saving their funds with the Fleximax savings product. By paying attention to the marketing mix factors, this can 
support the running of the company and be able to compete with conventional products that first existed.

Keywords - Customer Decision, Product, Price, Place, Promotion.

\section{PENDAHULUAN}

Saat ini industri perbankan semakin berkembang, terutama yang berbasis syariah. Bank syariah memberikan prinsip-prinsip yang adil dan terbuka dalam pengelolaan dana, oleh karena itu sistem perbankan syariah saat ini menjadi pilihan yang menarik bagi seluruh pengusaha dan masyarakat umum yang menggunakan jasa perbankan. Kehadiran bank syariah menjawab keperluan publik yang memberikan rasa aman dan nyaman saat melakukan transaksi menawarkan layanan untuk meningkatkan kepercayaan publik terhadap kegiatan perbankan khusunya di Indonesia.

Perkembangnya bank syariah tentunya melalui penjualan produk. Dari mulai pengimpun (funding), penyalur (financing), dan jasa (service). Pemasaran sangat penting bagi setiap perusahaan, terutama perusahaan komersial. Tujuan nya selain mendapatkan keuntungan yaitu untuk bertahan agar terus beroperasional dan mampu bersaing terutama bersaing dengan banl konvensional yang lebih dulu ada. Maka diperlukannya strategi pemasaran agar target-target perusahaan dapat tercapai.

Strategi pemasaran yang berkembang luas adalah strategi bauran pemasaran. berkaitan dengan menentukan cara perusahaan untuk memasarkan produk pada segmen pasar tertentu. Marketing mix adalah inti dari sistem pemasaran, variabel yang dapat dimanipulasi oleh perusahaan untuk mempengaruhi respon konsumen (Assauri 1998). Pelaku perbankan syariah harus mampu memahami dengan betul memgenai strategi pemasaran agar dapat mencapai keberhasilan meraup pangsa pasar. Terdapat beberapa faktor dalam bauran pemasaran diantaranya product, price, promotion, place, people, process, physical evidence dan shariah compliance yang menjadi pertimbangan uatama untuk menentukan straegi yang tepat menawarkan produk perbankan kepada msyarakat.

Namun dalam penelitian ini hanya akan meneliti faktor product, price, promotion dan place. Produk ialah segala sesuatu yang dapat ditawarkan produsen untuk diperhatikan, diminta, dicari, dibeli, digunakan ataupun dikonsumsi oleh pasar untuk memenuhi kebutuhan (Tjiptono 2002). Menurut Kotler dan Armstrong produk ialah segala sesuatu yang dapat ditawarkan ke pasar untuk menarik perhatian, pembelian, penggunaan ataupun konsumsi guna memuaskan keinginan atau kebutuhan (P Kotler and Armstrong 2000).

Ada perbedaan antara produk bank syariah dan bank konvensional. Dalam produk bank syariah terdapat internalisasi nilai-nilai syariah pada operasionalnya baik itu produk maupun jasa. Produk yang ditawarkan bank syariah antara lainproduk penghimpun dana (funding), penyalur dana (financing) dan produk jasa (service) (Jalaludin 2018). Dari semua produk yang tersedia menggunakan prinip bagi hasil dan bebas dari riba (Uatma 2009).

Harga merupakan nilai produk atau layanan diukur menggunakan jumlah uang yang dihabiskan pelanggan untuk membeli produk atau layanan (Reality 2008). Menurut Wiliam J Stanton harga ialah sejumlah uang yang diperlukan agar memperoleh beberapa kombinasi produk atau pelayanan (Angipora 2002). Dalam perbagai jenis usaha harga menjadi kunci strategi karena berbagai faktor seperti deregulasi, persaingan yang semakin ketat, tinggi dan rendahnya pertumbuhan ekonomi serta mencari peluang usaha. Harga

EKSISBANK (Ekonomi Syariah dan Bisnis Perbankan), Volume 5, Nomor 1, Juni 2021 
juga dapat mempengaruhi kinerja perusahaan dan akan memperngaruhi persepsi pembeli.

Tempat atau lokasi adalah tempat tertentu atau permanen perusahaan keputusan alokasi mengenai akses terhadap layanan pelanggan (Lupiyoadi 2001). Tempat merupakan lokasi dimana diperjualbelikannya produk bank (Kasmir 2004). Tempat yang startegis menjadi akses yang paling penting dalam menjalankan usaha, karena jika keberadaan bank syariah dapat terjangkau oleh masyarakat akan mempermudah dalam penjualan barang dan jasa karena penetapan tempat ini mendukung kelancaran kegiatan pemasaran (Ibad, Arifin, and Priyono 2018).

Hal yang perlu diperhatikan oleh manajemen perusahaan yaitu promosi. Tersedianya produk yang ada di bank syariah memerlukan promosi agar dikenal oleh masyarakat. Promosi adalah kegiatan komunikasi yang bersifat persuasif dan memberikan informasi tentang produk atau jasa yang ditawarkan kepada calon pembeli antara lain promosi penjualan, iklan, sales force, dan hubungan masyarakat dan pemasaran langsung (Philip Kotler 2003).

Dari beberapa faktor bauran pemasaran yang telah dipaparkan tentunya akan mempengaruhi keputusan pembelian. Keputusan pembelian adalah proses terintegritas yang menggabungkan pengetahuan untuk mengevaluasi dua atau lebih perilaku alternatif dan memilih salah satunya (Philip Kotler and Keller 2009). Dari berbgai faktor dalam bauran pemasaran akan memberikan dampak signifikan terhadap keputusan nasabah untuk menentukan pembelian produk atau jasa.

Bank Panin Dubai Syariah adalah salah satu bank syariah terbesar yang mempunyai izin operasional dari Bank Indonesia pada tanggal 06 Oktober 2009 kemdudian beroperasi sebagai bank syariah pada tanggal 02 Desember 2009 (Paninbanksyariah 2021).
Bank Panin Dubai Syariah telah tersebar di beberapa kota salah satunya yaitu pada kantor cabang Bandung sebagai objek pada penelitian ini. Terdapat beberapa produk yang tersedia salah satunya yaitu simpanan fleximax. Simpana fleximax adalah setoran rencana pembayaran fleksibel dengan hasil optimal (Panindubaisyariah 2021).

Berikut data jumlah nasabah Simpanan Fleximax PT. Bank Panin Dubai Syariah KCU Bandung selama kurun waktu lima tahun.

Tabel 1 Jumlah Nasabah Simpanan Fleximax 5 PT Bank Panin Dubai Syariah Tahun 2015-2019

\begin{tabular}{|c|c|c|}
\hline Tahun & Jumlah & $\begin{array}{c}\text { Keterangan } \\
(\boldsymbol{\%})\end{array}$ \\
\hline $\mathbf{2 0 1 5}$ & 60 & - \\
\hline $\mathbf{2 0 1 6}$ & 66 & 10 \\
\hline $\mathbf{2 0 1 7}$ & 76 & 15 \\
\hline $\mathbf{2 0 1 8}$ & 70 & -8 \\
\hline $\mathbf{2 0 1 9}$ & 77 & 10 \\
\hline
\end{tabular}

Sumber: PT Bank Panin Dubai Syariah KCU Bandung Tahun 2020

Berdasarkan tabel diatas diketahui bahwa nasabah Simpanan Fleximax dalam 5 tahun terakhir mengalami fluktuasi peningkatan pada tahun 2016, 2017 dan 2019, yaitu sebesar $10 \%$ pada tahun 2016 , sebesar $15 \%$ pada tahun 2017 dan sebesar $10 \%$ pada tahun 2019. Sementara pada tahun 2018 mengalami penurunan sebesar $-8 \%$. Untuk mendapat jumlah nasabah tersebut di setiap tahunnya tentu tidak mudah dibutuhkan strategi pemasaran yang bagus agar menambah jumlah nasabah dan juga untuk mempertahankan nasabah simpanan fleximax.

Memandang banyak hal yang menarik untuk diteliti, maka penulis mengambil judul "Pengaruh Product, Price, Place dan Promotion terhadap Keputusan Nasabah Simpanan Fleximax di PT Bank Panin Dubai Syariah KCU Bandung”. 
Pada artikel ini penulis akan menganalisis pengaruh Product, Price, Place dan Promotion terhadap Keputusan Nasabah Tabungan Fleximax Bank Panin Dubai Syariah KCU Bandung.

\section{Product}

Produk menjadi titik pusat dalam berjalannya sebuah usaha. Karena produk ini akan di pasarkan lalu menghasilkan keuntungan sehingga perusahaan dapat berkembang dan bersaing. Secara konseptual merupakan persamaan subyektif produsen yang dapat ditawarkan untuk mencapai tujuan organisasi melalui pemenuhan dan kebutuhan konsumen, sesuai dengan kompetensi dan kapitalis organsiasi dan daya belinya (Tjiptono 2002). Produk juga dapat didefinisikan sebagai atribut nyata atau tidak nyata, termasuk kemasan, warna, harga, kualitas dan merk ditambah dengan layanan dan reputasi penjualannya (Stanton and Lambert 1994). Indikator produk meliputi kualitas, keanekaragaman dan keunggulan ( $\mathrm{P}$ Kotler and Armstrong 2000).

\section{Price}

Price ialah sejumlah uang yang dibutuhkan untuk untuk membeli barang beserta jasa tertentu atau kombinasi keduanya (Gitosudarmo 2000). Berperan penting dalam pemasaran dan menjadi faktor kendali, karena akan berpengaruh terhadap hasil penjualan, harga juga harus sesuai dengan kualitas produk atau jasa (Supriyono 2014). Saat menetapkan harga perusahaan harus menentukan nilai keadilan. Apabila konsumen sudah mengetahui kekurangan dari produk yang diusulkan, maka sebaiknya harganya disesuaikan dengan kondisi produk (Kartajaya 2006).

\section{Place}

Lokasi atau place erat kaitannya dengan keberadaan perusahaan melalukan operasi atau kegiatannya (Lupiyoadi 2001). Dalam menentukan lokasi ini perlu adanya pertimbangan dari beberapa faktor, mulai dari akses yang dilalui mudah terjangkau sarana transportasi umum yang nantinya akan mempermudah konsumen dan operasional perusahaan. Visabilitas harus diperhatikan karena ini akan mempengaruhi jarak pandang normal (Syafirah 2019). Lalu lintas harus ramai yang banyak dilalui banyak orang, karena jika keberadaan perusahaan di tempat yang sepi akan mengalami kesulitan dalam operasionalnya. Selanjutnya banyak faktor lain yang harus dipertimbangan seperti sarana area parkir, ekpansi, lingkungan, persaingan, dan peraturan pemerintah (Tjiptono 2002).

\section{Promotion}

Promosi adalah upaya pemasaran baik di media maupun non media untuk merangsang konsumen sedemikian rupa sehingga timbul minat melalui informasi produk (Sutrisna 2003). Kemampuan persuasif mempunyai peran yang sangat penting harus di tonjolkan pada proses pemasaran. Hal ini berkaitan dengan sumber daya manusia, karena personal seeling, jaminan citra diri, penampilan, kecakapan, dan kepribadian menjadi ciri-ciri prinsip seseorang pemasara mampu meyakinkan masyarakat dengan keunggulan produknya (Tasruddin 2015).

\section{Keputusan Nasabah}

Bank harus menyeimbangkan perilaku nasabah yang terus bergerak untuk menghadapi berbagai kelompok nasabah. Bank juga perlu memahami apa yang mereka pikirkan (kognisi) dan mereka rasakan (pengaruh) serta perilaku dan kejadian di sekitar mereka (Marzuki 2010). Keputusan nasabah adalah seseorang memutuskan untuk membuat pilihan yang mendukung pembelian barang atau jasa setelah melalui beberapa proses.

\section{Simpanan Felximax}

Simpanan fleximax ialah setoran simpanan fleksibel sesuai rencana dengan hasil optimal. Ini terdiri dari fungsi simpanan dalam mata 
uang rupiah, akun untuk perorangan maupun perusahaan setoran awal minimal 100 juta. Produk ini mempunyai keunggulan dari segi pengelolaan dana syariah dengan memberikan bonus yang optimal, memungkinkan mendapatkan bonus yang optimal, fleksibel dan adaptif untuk perencanaan keuangan (Panindubaisyariah 2021).

\section{TINJAUAN PUSTAKA}

Penelitian tentang Pengaruh Product, Price, Place Dan Promotion Terhadap Keputusan Nasabah Simpanan sudah banyak dilakukan oleh peneliti sebelumnya seperti penelitian yang dilakukan oleh peneliti-peneliti sebagai berikut:

A. Pengaruh promosi, lokasi, dan kualitas layanan terhadap keputusan pembelian nasabah Bank Mandiri Surabaya (Fajar Fahrudin and Yulianti 2015)

Penelitian ini bertujuan untuk mengetahui pengaruh promosi, lokasi, dan kualitas pelayanan terhadap keputusan pembelian pelanggan dengan sampel Bank Mandiri Surabaya. Sampel penelitian terdiri dari 74 nasabah Bank Mandiri Surabaya yang dipilih melalui teknik judgment sampling. Regresi dengan software SPSS digunakan untuk analisis data dan pengujian hipotesis. Hasil penelitian menunjukkan bahwa promosi dan lokasi berpengaruh tidak signifikan terhadap keputusan pembelian pelanggan Bank Mandiri Surabaya. Namun, kualitas layanan berpengaruh positif dan signifikan terhadap keputusan pembelian konsumen Bank Mandiri Surabaya. Temuan penelitian ini menunjukkan bahwa Bank Mandiri Surabaya harus memperhatikan kualitas layanan dalam rangka meningkatkan jumlah pelanggan tabungan mereka.

Perbedaan penelitian terdahulu dengan penelitian saat ini adalah variable bebas yang digunakan pada penelitian ini menggunakan semua indicator marketing Mix dan tidak digabungkan dengan variable kualitas pelayanan, serta lokasi penelitian yang berbeda pula antara peneliti terdahulu dengan peneliti saat ini.

B. Bauran Pemasaran Dan Pengaruhnya Terhadap Keputusan Menjadi Nasabah Di BPR Prisma Dana Manado (Kondoy, Tewal, and Worang3 2016)

Penelitian ini bertujuan untuk menganalisis pengaruh bauran pemasaran terhadap keputusan menjadi nasabah di BPR Prisma Dana Manado. Metode analisis dalam penelitian ini adalah deskriptif kuantitatif dengan menggunakan tehnik analisis regresi linear berganda. Berdasarkan hasil uji simultan didapatkan nilai Fhitung dari variabel produk, harga, tempat dan promosi adalah sebesar 218,101. Sedangkan Ftabel pada tingkat signifikansi 0,05 derajat bebas $(n-1)=2$ adalah 3,09. Sehingga disimpulkan bahwa $F_{\text {hitung }}(218,101)$ lebih besar dari Ftabel $(3,09)$. Hasil penelitian diketahui bahwa variable produk, harga, tempat dan promosi secara bersama-sama berpengaruh terhadap keputusan menjadi nasabah di BPR Prisma Dana Manado. Berdasarkan uji koefisien determinasi menunjukkan bahwa keputusan nasabah dipengaruhi oleh variabel independen yang meliputi produk, harga, tempat dan promosi sebesar 90,2\%, sedangkan sisanya $9,8 \%$ dijelaskan oleh variabel lain yang tidak terdapat dalam penelitian ini.

Perbedaan penelitian terdahulu dengan penelitian saat ini adalah variable bebas yang digunakan pada penelitian ini menggunakan semua indicator marketing Mix dan tidak digabungkan dengan variable kualitas pelayanan, serta lokasi penelitian yang berbeda pula antara peneliti terdahulu dengan peneliti saat ini.

Pada artikel ini menganalisis pengaruh Product, Price, Place dan Promotion terhadap 
Keputusan Nasabah Tabungan Fleximax Bank Panin Dubai Syariah KCU Bandung. Product merupakan segala sesuatu yang siap dipasarkan oleh produsen untuk mendapatkan perhatian, diminta sampai dengan dibeli untuk pemenuhan kebutuhan. Price ialah nilai suatu barang atau jasa yang diukur dengan uang guna mendapatkan barang atau manfaatnya. Place merupakan lokasi yang bersifat tetap atau keberadaan sebuah perusahaan. Promotion ialah komunikasi penjualan yang bersifat persuasive mempengaruhi konsumen agar tertarik dengan produk yang ditawarkan. Hasil penelitain menunjukkan semua variabel independen berpengaruh terhadap variabel dependen

\section{Analisis Pengaruh Faktor Bauran Pemasaran terhadap Pertimbangan Nasabah dalam Memilih Bank Syariah di Kota Medan (K. and Surachman 2010)}

Tujuan dari penelitian ini adalah untuk menganalisis pengaruh bauran pemasaran, yaitu produk, harga, promosi, tempat, orang, proses, dan bukti fisik, terhadap pertimbangan nasabah dalam memilih bank syariah. Dan juga untuk menginformasikan faktor mana yang paling dominan dari ketujuh faktor tersebut untuk dipertimbangkan oleh pelanggan. Penelitian lapangan adalah kota Medan dengan populasi seluruh nasabah perorangan bank syariah Medan melalui Bank Syariah Mandiri Kantor Cabang Medan; Bank Muamalat Indonesia, Kantor Cabang Medan; BNI Syariah Kantor Cabang Medan menggunakan metode purposive sampling dengan jumlah responden 100 orang dalam menyelesaikan survei. Pengujian hipotesis melibatkan analisis regresi berganda. Hasil penelitian menunjukkan hanya tiga dari tujuh faktor bauran pemasaran yaitu produk, tempat, dan orang yang secara signifikan mempengaruhi pertimbangan nasabah dalam memilih bank syariah di Medan. Empat faktor lainnya, harga, promosi, proses, dan bukti fisik tidak berpengaruh signifikan terhadap pertimbangan pelanggan. Salah satu faktor yang memberikan pertimbangan paling dominan adalah produk.

Perbedaan penelitian terdahulu dengan penelitian saat ini adalah variable bebas yang digunakan pada penelitian ini menggunakan semua indicator marketing Mix dan tidak digabungkan dengan variable kualitas pelayanan, serta lokasi penelitian yang berbeda pula antara peneliti terdahulu dengan peneliti saat ini.

Pada artikel ini menganalisis pengaruh Product, Price, Place dan Promotion terhadap Keputusan Nasabah Tabungan Fleximax Bank Panin Dubai Syariah KCU Bandung. Product merupakan segala sesuatu yang siap dipasarkan oleh produsen untuk mendapatkan perhatian, diminta sampai dengan dibeli untuk pemenuhan kebutuhan. Price ialah nilai suatu barang atau jasa yang diukur dengan uang guna mendapatkan barang atau manfaatnya. Place merupakan lokasi yang bersifat tetap atau keberadaan sebuah perusahaan. Promotion ialah komunikasi penjualan yang bersifat persuasive mempengaruhi konsumen agar tertarik dengan produk yang ditawarkan. Hasil penelitain menunjukkan semua variabel independen berpengaruh terhadap variabel dependen

D. Pengaruh Service Marketing Mix terhadap Keputusan Nasabah untuk Menabung Pada PT. Bank Mayapada Internasional TBK Cabang A.Yani Pekanbaru (Wijaya and Ariyani 2018)

Penelitian ini bertujuan untuk mengetahui pengaruh bauran pemasaran jasa (produk, harga, lokasi, promosi, proses, orang dan bukti fisik) terhadap keputusan nasabah untuk menabung pada PT Bank Mayapada International Tbk Cabang A.Yani Pekanbaru. Penelitian ini menggunakan sampel sebanyak 
100 responden dengan menggunakan teknik accindental sampling. Teknik analisa data menggunakan analisa regresi linear berganda. Hasil penelitian memperlihatkan bahwa produk, tempat, proses dan orang berpengaruh signifikan terhadap keputusan nasabah untuk menabung sedangkan harga, promosi dan bukti fisik tidak berpengaruh signifikan terhadap keputusan nasabah untuk menabung pada PT Bank Mayapada International Tbk Cabang A.Yani Pekanbaru.

Perbedaan penelitian terdahulu dengan penelitian saat ini adalah variable bebas yang digunakan pada penelitian ini menggunakan semua indicator marketing Mix dan tidak digabungkan dengan variable kualitas pelayanan, serta lokasi penelitian yang berbeda pula antara peneliti terdahulu dengan peneliti saat ini.

Pada artikel ini menganalisis pengaruh Product, Price, Place dan Promotion terhadap Keputusan Nasabah Tabungan Fleximax Bank Panin Dubai Syariah KCU Bandung. Product merupakan segala sesuatu yang siap dipasarkan oleh produsen untuk mendapatkan perhatian, diminta sampai dengan dibeli untuk pemenuhan kebutuhan. Price ialah nilai suatu barang atau jasa yang diukur dengan uang guna mendapatkan barang atau manfaatnya. Place merupakan lokasi yang bersifat tetap atau keberadaan sebuah perusahaan. Promotion ialah komunikasi penjualan yang bersifat persuasive mempengaruhi konsumen agar tertarik dengan produk yang ditawarkan. Hasil penelitain menunjukkan semua variabel independen berpengaruh terhadap variabel dependen

E. Analisis Pengaruh Bauran Pemasaran Terhadap Keputusan Nasabah Dalam Memilih Produk Tabungan Batara Pada Bank BTN Cabang Pontianak (Kristanto 2013)
Penelitian ini bertujuan untuk; 1) Untuk menganalisis pengaruh variabel produk (product), harga (price), tempat (place), promosi (promotion), orang (people), bukti fisik (physical evidence) dan proses (process) baik secara simultan maupun parsial terhadap keputusan nasabah untuk memilih produk Tabungan Batara di Bank BTN Cabang Pontianak, 2) Untuk menganalisis variabel bauran pemasaran yang berpengaruh secara dominan terhadap keputusan nasabah untuk memilih produk Tabungan Batara di Bank BTN Cabang Pontianak. Penelitian ini menggunakan metode explanatory research (hubungan/pengaruh) melalui suatu survei yang bertujuan untuk mencari gambaran yang sistematis dan fakta yang akurat. Pengumpulan data dilakukan dengan cara membagikan kuesioner kepada 200 orang yang memilih Tabungan Batara di Bank BTN Cabang Pontianak. Hasil penelitian menunjukkan bahwa; 1) Variabel produk (product), harga (price), tempat (place), promosi (promotion), orang (people), bukti fisik (physical evidence) dan proses (process) memiliki pengaruh yang positif dan signifikan baik secara parsial maupun simultan terhadap keputusan nasabah untuk memilih produk Tabungan Batara di Bank BTN Cabang Pontianak, 2) Faktor people (karyawan) memiliki pengaruh yang dominan terhadap keputusan nasabah untuk memilih produk Tabungan Batara di Bank BTN Cabang Pontianak.

Perbedaan penelitian terdahulu dengan penelitian saat ini adalah variable bebas yang digunakan pada penelitian ini menggunakan semua indicator marketing Mix dan tidak digabungkan dengan variable kualitas pelayanan, serta lokasi penelitian yang berbeda pula antara peneliti terdahulu dengan peneliti saat ini.

Pada artikel ini menganalisis pengaruh Product, Price, Place dan Promotion terhadap 
Keputusan Nasabah Tabungan Fleximax Bank Panin Dubai Syariah KCU Bandung. Product merupakan segala sesuatu yang siap dipasarkan oleh produsen untuk mendapatkan perhatian, diminta sampai dengan dibeli untuk pemenuhan kebutuhan. Price ialah nilai suatu barang atau jasa yang diukur dengan uang guna mendapatkan barang atau manfaatnya. Place merupakan lokasi yang bersifat tetap atau keberadaan sebuah perusahaan. Promotion ialah komunikasi penjualan yang bersifat persuasive mempengaruhi konsumen agar tertarik dengan produk yang ditawarkan. Hasil penelitain menunjukkan semua variabel independen berpengaruh terhadap variabel dependen.

\section{F. Pengaruh Implementasi Marketing Mix} Terhadap Keputusan Nasabah Dalam Memilih Produk Tabungan Bank Danamon (Studi Kasus pada Nasabah Bank Danamon Citraland Semarang) (Baskoro, Hasiholan, and Seputra 2021)

Bank harus membangun teknik menampilkan yang dapat mengikuti perilaku nasabah yang dinamis atau terus bergerak secara konsisten. Untuk mengelola pertemuan klien yang berbeda, diperlukan teknik promosi yang beragam. Objek eksplorasi yang digunakan adalah semua populasi dalam investigasi ini sebagian besar adalah nasabah Bank Danamon Citral dan Semarang yang memilih dana cadangan yang sering digunakan adalah dana Investasi Danamon Flexi Max selama 3 tahun terakhir, 2018-2020, berjumlah 484 individu yang telah melakukan pertukaran. Dari populasi absolut sebanyak 484 klien dengan tingkat kesalahan pada contoh kesalahan yang ditetapkan sebesar $10 \%$, dapat diperoleh contoh 83 responden. Sebanyak 83 responden yang dipilih merupakan nasabah Bank Danamon yang telah melakukan penukaran sepanjang akhir 2018 - 2020. Dengan memanfaatkan SPSS
Form 26. Hasil investigasi selanjutnya adalah item tersebut mempengaruhi pilihan nasabah. Area secara positif mempengaruhi pilihan klien. Kemajuan memiliki hasil konstruktif yang kritis pada pilihan klien. Individu secara positif mempengaruhi pilihan klien. Konsekuensi dari hasil SPSS menunjukkan bahwa estimasi faktor item, luas, kemajuan dan individu memiliki estimasi $F$ yang ditentukan sebesar 0.878 dengan tingkat kepentingan 0.481 , dengan alasan $\mathrm{F}$ harga yang ditentukan adalah 0.878> F tabel 3.96 dan tingkat kepentingannya. esteem (Sig.) $0.878<0.05$ dan Ditandai positif, hal ini cenderung disimpulkan bahwa $\mathrm{H} 0$ diberhentikan dan $\mathrm{Ha}$ diakui, yang menyiratkan bahwa item, area, kemajuan dan individu sekaligus mempengaruhi pilihan klien. Kata Kunci : Marketing Mix, Produk, Lokasi, Promosi, People, Keputusan Nasabah.

Perbedaan penelitian terdahulu dengan penelitian saat ini adalah variable bebas yang digunakan pada penelitian ini menggunakan semua indicator marketing Mix dan tidak digabungkan dengan variable kualitas pelayanan, serta lokasi penelitian yang berbeda pula antara peneliti terdahulu dengan peneliti saat ini.

Pada artikel ini menganalisis pengaruh Product, Price, Place dan Promotion terhadap Keputusan Nasabah Tabungan Fleximax Bank Panin Dubai Syariah KCU Bandung. Product merupakan segala sesuatu yang siap dipasarkan oleh produsen untuk mendapatkan perhatian, diminta sampai dengan dibeli untuk pemenuhan kebutuhan. Price ialah nilai suatu barang atau jasa yang diukur dengan uang guna mendapatkan barang atau manfaatnya. Place merupakan lokasi yang bersifat tetap atau keberadaan sebuah perusahaan. Promotion ialah komunikasi penjualan yang bersifat persuasive mempengaruhi konsumen agar tertarik dengan produk yang ditawarkan. Hasil penelitain menunjukkan semua variabel 
independen berpengaruh terhadap variabel dependen

\section{G. Pengaruh Bauran Pemasaran Jasa Terhadap Keputusan Menabung (Survei Pada Nasabah Bank Muamalat Cabang Malang) (Fajri 2013)}

Hasil penelitian menunjukan bahwa variabel Produk (X1), Harga (X2), Promosi (X3), Proses (X4), Orang (X5), Bukti Fisik (X6), Lokasi (X7) secara bersama-sama atau simultan mempunyai pengaruh yang signifikan terhadap Proses Keputusan Menabung (Y) dengan nilai Fhitung sebesar 8,705 yang lebih besar dari Ftabel $(8,705>$ $2,316)$ dengan tingkat sig.F lebih kecil dari $\alpha$ $(0,05)$ dan nilai Adjusted R Square yaitu sebesar 0,357. Hal ini berarti bahwa kemampuan variabel-variabel Bauran Pemasaran Jasa secara simultan memberikan kontribusi terhadap Proses Keputusan Menabung adalah sebesar 35,7\% sedangkan sisanya sebesar 64,3 \% dipengaruhi oleh variabel lain yang tidak dibahas dalam penelitian ini. Hasil penelitian ini juga menunjukan bahwa variabel Produk (X1) merupakan variabel yang berpengaruh dominan terhadap Proses Keputusan Menabung (Y) yang ditunjukan dengan koefisien beta tertinggi yaitu 0,274 dan nilai t hitung yang paling besar yaitu 2,493. Kesimpulan dari penelitian ini adalah: 1). Bauran Pemasaran Jasa yang terdiri dari Produk (X1), Harga (X2), Promosi (X3), Proses (X4), Orang (X5), Bukti Fisik (X6), Lokasi (X7) berpengaruh positif dan signifikan secara simultan terhadap Proses Keputusan Menabung (Y). 2). Variabel Produk (X1) merupakan variabel yang berpengaruh dominan terhadap Proses Keputusan Menabung (Y).

Perbedaan penelitian terdahulu dengan penelitian saat ini adalah variable bebas yang digunakan pada penelitian ini menggunakan semua indicator marketing Mix dan tidak digabungkan dengan variable kualitas pelayanan, serta lokasi penelitian yang berbeda pula antara peneliti terdahulu dengan peneliti saat ini.

Pada artikel ini menganalisis pengaruh Product, Price, Place dan Promotion terhadap Keputusan Nasabah Tabungan Fleximax Bank Panin Dubai Syariah KCU Bandung. Product merupakan segala sesuatu yang siap dipasarkan oleh produsen untuk mendapatkan perhatian, diminta sampai dengan dibeli untuk pemenuhan kebutuhan. Price ialah nilai suatu barang atau jasa yang diukur dengan uang guna mendapatkan barang atau manfaatnya. Place merupakan lokasi yang bersifat tetap atau keberadaan sebuah perusahaan. Promotion ialah komunikasi penjualan yang bersifat persuasive mempengaruhi konsumen agar tertarik dengan produk yang ditawarkan. Hasil penelitain menunjukkan semua variabel independen berpengaruh terhadap variabel dependen

\section{H. Analisis Pengaruh Marketing Mix} Terhadap Pengambilan Keputusan Nasabah Menabung Pada Bank Jateng Cabang Ungaran (Annurfa and Sunindyo 2020)

Penelitian ini bertujuan untuk menganalisis dan mengidentifikasi pengaruh signifikansi produk, harga, promosi dan tempat terhadap keputusan menabung pada Bank Jateng Cabang Ungaran dan secara parsial. Data dikumpulkan melalui kuesioner kepada 100 responden yang merupakan nasabah tabungan di Bank Jateng Cabang Ungaran. Yang diperoleh dengan menggunakan teknik purposive sampling. Uji asumsi klasik yaitu uji normalitas, uji multikoloniaritas, uji heteroskedastisitas dan uji analisis linier berganda dan koefisien determinasi. Hipotesis dibuktikan dengan menggunakan uji t dan uji F. Hasil penelitian ini menunjukkan bahwa 
produk, harga, promosi, tempat secara simultan berpengaruh signifikan terhadap keputusan pelanggan untuk menabung. Secara parsial terdapat satu variabel signifikan yang mempengaruhi keputusan nasabah penghematan promosi. Untuk variabel produk, harga, tempat tidak berpengaruh signifikan terhadap keputusan nasabah menabung di Bank Jateng Cabang Ungaran.

Perbedaan penelitian terdahulu dengan penelitian saat ini adalah variable bebas yang digunakan pada penelitian ini menggunakan semua indicator marketing Mix dan tidak digabungkan dengan variable kualitas pelayanan, serta lokasi penelitian yang berbeda pula antara peneliti terdahulu dengan peneliti saat ini.

Pada artikel ini menganalisis pengaruh Product, Price, Place dan Promotion terhadap Keputusan Nasabah Tabungan Fleximax Bank Panin Dubai Syariah KCU Bandung. Product merupakan segala sesuatu yang siap dipasarkan oleh produsen untuk mendapatkan perhatian, diminta sampai dengan dibeli untuk pemenuhan kebutuhan. Price ialah nilai suatu barang atau jasa yang diukur dengan uang guna mendapatkan barang atau manfaatnya. Place merupakan lokasi yang bersifat tetap atau keberadaan sebuah perusahaan. Promotion ialah komunikasi penjualan yang bersifat persuasive mempengaruhi konsumen agar tertarik dengan produk yang ditawarkan. Hasil penelitain menunjukkan semua variabel independen berpengaruh terhadap variabel dependen

I. Pengaruh Strategi Marketing Terhadap Keputusan Nasabah Menggunakan Produk Tabungan Simpatik (Studi Pada PT.Bank Mandiri Syariah Kantor Cabang Setia Budi Medan) (Sari and Murtani 2020)

Penelitian bertujuan untuk mengetahui dan menganalisis seberapa besar dampak pengaruh bauran pemasaran (4P) terhadap
Keputusan Nasabah Menggunakan Produk Tabungan Simpatik" (Studi Pada PT. Bank Syariah Mandiri Kantor Cabang Setia Budi Medan), dan untuk mengetahui variabel mana yang paling dominan terhadap kebijakan nasabah Menggunakan Produk Tabungan Simpatik" (Studi Di Bank Mandiri Syariah Kantor Cabang Setia Budi Medan). Jenis Penelitian ini adalah penelitian Kuantitaif. Menggunakan data yang bersifat angka-angka dianalisis melalui statistik. Data penelitian ini diperoleh dari hasil penyebaran kuesioner di PT. Bank Bank Mandiri Syariah Kantor Cabang Setia Budi Medan dengan jumlah 50 responden. Data dianalisis menggunakan uji validitas dan uji reliabilitas, uji asumsi klasik, analisis regresi berganda, uji $F$ dan uji $T$ dengan bantuan software SPSS 23. Hasil penelitian melalui uji $\mathrm{F}$ f-hitung sebesar 19,312 nilai ini lebih besar dari f-tabel yaitu 4.03 atau f-hitung 19,312 > f-tabel yaitu 4.03, dengan probabilitas 0.000 , menunjukkan secara simultan variabel produk, price, plice, promotion berpengaruh positif dan signifikan terhadap Keputusan Nasabah Menggunakan Produk Tabungan Simpatik" (Studi Di Bank Mandiri Syariah Kantor Cabang Setia Budi Medan). Sementara Hasil Uji T menunjukkan bahwa variabel produk thitung dan $\mathrm{t}$ tabel,$(3,565>0,2787)$, atau sig dan $\alpha(, 001<$ $0.05)$, place $(6,973<0,2787)$, atau sig dan $\alpha$ $(, 000<0.05)$, secara parsial berpengaruh positif dan signifikan. Sementara variabel price , (1,078> 0,2787), atau sig dan $\alpha$ $(0,287>0.05)$, promotion $(-1,063>0,2787)$, atau sig dan $\alpha(0,293>0.05)$, secara parsial tidak berpengaruh dan tidak signifikan. Adapun variabel yang mendominasi yaitu place berpengaruh positif dan signifikan dalam Keputusan Nasabah Menggunakan Produk Tabungan Simpatik" (Studi Di Bank Mandiri Syariah Kantor Cabang Setia Budi Medan). Perbedaan penelitian terdahulu dengan penelitian saat ini adalah variable 
bebas yang digunakan pada penelitian ini menggunakan semua indicator marketing Mix dan tidak digabungkan dengan variable kualitas pelayanan, serta lokasi penelitian yang berbeda pula antara peneliti terdahulu dengan peneliti saat ini.

Pada artikel ini menganalisis pengaruh Product, Price, Place dan Promotion terhadap Keputusan Nasabah Tabungan Fleximax Bank Panin Dubai Syariah KCU Bandung. Product merupakan segala sesuatu yang siap dipasarkan oleh produsen untuk mendapatkan perhatian, diminta sampai dengan dibeli untuk pemenuhan kebutuhan. Price ialah nilai suatu barang atau jasa yang diukur dengan uang guna mendapatkan barang atau manfaatnya. Place merupakan lokasi yang bersifat tetap atau keberadaan sebuah perusahaan. Promotion ialah komunikasi penjualan yang bersifat persuasive mempengaruhi konsumen agar tertarik dengan produk yang ditawarkan. Hasil penelitain menunjukkan semua variabel independen berpengaruh terhadap variabel dependen

J. Pengaruh Bauran Pemasaran Jasa (Product, Price, Place, Promotion, Process, People, And Physical Evidence) Terhadap Keputusan Pembelian (Study Kasus Pada Jasa Transportasi CV King Tour And Travel) (Ibad, Arifin, and Priyono 2018)

Penelitian ini bertujuan untuk menunjukkan pengaruh bauran pemasaran jasa yang dilakukan CV King Tour and Travel secara simultan dan parsial terhadap keputusan pembelian jasa transportasi. Penelitian ini dilakukan pada perusahaan CV King Tour and Travel. Penelitian ini menggunakan deskriptif kuantitatif dengan teknik pengambilan sampel dengan teknik non probabilty sampling. Jenis data yang digunakan dalam penelitian adalah time series dengan prosedur pengumpulan data melalui penyampaian kuesioner kepada konsumen terpilih sebagai sampel. Hasil analisis data dan hipotesis menunjukkan bahwa bauran layanan pemasaran yang terdiri dari (Produk, Harga, Tempat, Promosi, Proses, Orang, dan Bukti Fisik) berpengaruh positif terhadap keputusan pembelian. Dan itu menunjukkan hasil yang signifikan dari masing-masing variabel bauran pemasaran yaitu Promosi dan Bukti Fisik).

Perbedaan penelitian terdahulu dengan penelitian saat ini adalah variable bebas yang digunakan pada penelitian ini menggunakan semua indicator marketing Mix dan tidak digabungkan dengan variable kualitas pelayanan, serta lokasi penelitian yang berbeda pula antara peneliti terdahulu dengan peneliti saat ini.

Pada artikel ini menganalisis pengaruh Product, Price, Place dan Promotion terhadap Keputusan Nasabah Tabungan Fleximax Bank Panin Dubai Syariah KCU Bandung. Product merupakan segala sesuatu yang siap dipasarkan oleh produsen untuk mendapatkan perhatian, diminta sampai dengan dibeli untuk pemenuhan kebutuhan. Price ialah nilai suatu barang atau jasa yang diukur dengan uang guna mendapatkan barang atau manfaatnya. Place merupakan lokasi yang bersifat tetap atau keberadaan sebuah perusahaan. Promotion ialah komunikasi penjualan yang bersifat persuasive mempengaruhi konsumen agar tertarik dengan produk yang ditawarkan. Hasil penelitain menunjukkan semua variabel independen berpengaruh terhadap variabel dependen

\section{K. Pengaruh Citra Merek Dan Promosi Penjualan Terhadap Keputusan Nasabah Memilih Tabungan Bank Syariah Mandiri (Indratama and Artanti 2014)}

Indonesia merupakan negara yang mayoritas penduduknya beragama Islam. Kondisi tersebut di masyarakat kita menunjukkan tren perubahan, dimana 
sebelumnya sistem perbankan konvensional cenderung lebih disukai, dan beralih menggunakan sistem perbankan berbasis syariah. Orang cenderung menggunakan citra merek sebagai arah untuk mengevaluasi suatu produk. Di sisi lain bank akan menerapkan strategi pemasaran yang bertujuan untuk mempengaruhi masyarakat, salah satunya melalui promosi penjualan. Penelitian ini bertujuan untuk membahas dan menganalisis pengaruh citra merek dan promosi penjualan terhadap keputusan nasabah memilih tabungan Bank Syariah Mandiri. Sampel dalam penelitian ini adalah nasabah yang mendapatkan layanan promosi penjualan untuk kategori produk tabungan berjumlah 200 responden dengan teknik accidental sampling. Pengumpulan data dilakukan dengan kuesioner, sedangkan teknik analisis data menggunakan analisis regresi berganda. Berdasarkan hasil pengujian diketahui bahwa citra merek dan promosi penjualan berpengaruh signifikan terhadap keputusan pembelian.

Perbedaan penelitian terdahulu dengan penelitian saat ini adalah variable bebas yang digunakan pada penelitian ini menggunakan semua indicator marketing Mix dan tidak digabungkan dengan variable kualitas pelayanan, serta lokasi penelitian yang berbeda pula antara peneliti terdahulu dengan peneliti saat ini.

Pada artikel ini menganalisis pengaruh Product, Price, Place dan Promotion terhadap Keputusan Nasabah Tabungan Fleximax Bank Panin Dubai Syariah KCU Bandung. Product merupakan segala sesuatu yang siap dipasarkan oleh produsen untuk mendapatkan perhatian, diminta sampai dengan dibeli untuk pemenuhan kebutuhan. Price ialah nilai suatu barang atau jasa yang diukur dengan uang guna mendapatkan barang atau manfaatnya. Place merupakan lokasi yang bersifat tetap atau keberadaan sebuah perusahaan.
Promotion ialah komunikasi penjualan yang bersifat persuasive mempengaruhi konsumen agar tertarik dengan produk yang ditawarkan. Hasil penelitain menunjukkan semua variabel independen berpengaruh terhadap variabel dependen

\section{METODOLOGI PENELITIAN}

Penelitin ini menggunakan metode penelitian kuantitatif asosiatif yang dilakukan untuk mendefiniskan hubungan antara dua variabel atau lebih Dalam penelitian ini menggunakan data primer yang didapatkan dari tanggapan terhadap keputusan menjadi nasabah pada simpanan fleximax melalui kuisioner dan wawancara dengan jumlah sampel sebanyak 65 orang. Metode analisis data diolah secara statistik dan secara kuantitatif.

\section{HASIL DAN PEMBAHASAN}

Sebelum dilakukannya analisis regresi peneliti telah melakukan uji asumsi klasik dengan tujuan agar analisis regresi dapat dikiketahui memenuhi atau ridak kiteria BLUE (Best Linear Unbiased Estimate).

Tabel 1 Hasil Uji Regresu Berganda Coefficients $^{\mathrm{a}}$

\begin{tabular}{|c|r|r|r|r|r|}
\hline \multirow{2}{*}{ Model } & \multicolumn{2}{|c|}{$\begin{array}{c}\text { Unstandard } \\
\text { ized } \\
\text { Coefficient } \\
\text { s }\end{array}$} & $\begin{array}{c}\text { Standa } \\
\text { rdized } \\
\text { Coeffi } \\
\text { cients }\end{array}$ & \multirow{2}{*}{$\mathrm{t}$} & Sig. \\
\cline { 2 - 4 } & $\mathrm{B}$ & $\begin{array}{c}\text { Std. } \\
\text { Error }\end{array}$ & Beta & & \\
\hline 1 (Co & 12. & & & 4.2 & .00 \\
$\mathrm{nsta}$ & 145 & 2.884 & & 11 & 0 \\
$\mathrm{nt})$ & & & 2.2 & .02 \\
$\mathrm{x} 1$ & .15 & .070 & .271 & 32 & 9 \\
& 5 & & & 2.1 & .03 \\
$\mathrm{x} 2$ & .19 & .092 & .259 & 28 & 7 \\
& 5 & & & 3.3 & .00 \\
x3 & .36 & .108 & .388 & 46 & 1
\end{tabular}




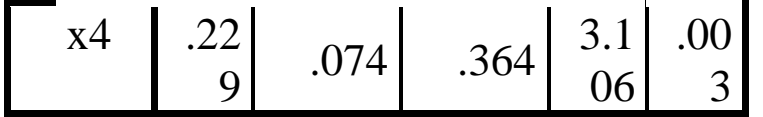

a. Dependent Variabel : Keputusan Nasabah Sumber : Hasil Penelitian 2020

Dari hasil penujian diatas, maka menghasilkan model persamaan sebagai berikut:

$$
\begin{gathered}
\mathrm{Y}=12,145+0,155 \mathrm{X}_{1}+0,195 \mathrm{X}_{2}+0.360 \\
\mathrm{X}_{3}+0,229 \mathrm{X}_{4}
\end{gathered}
$$

Merujuk dari persamaan yang telah disajikan, maka didapat nilai konstan (a) sebesar 12,145 mempunyai arti jika nilai variabel independen berada pada posisi tetap maka berdampak kepada variabel dependen berubah menjadi 12,145.

Pertama, untuk nilai koefsien $b_{1}$ sebesar 0,155 nilai ini berarti jika Product naik sebanyak satu persen maka memberikan pengaruh kepada variabel dependen meningkat menjadi 0,155 .

Kedua, untuk nilai koefsien $b_{2}$ sebesar 0,195 nilai ini berarti jika Price naik sebanyak satu persen maka memberikan pengaruh kepada variabel dependen meningkat menjadi 0,195 .

Ketiga, untuk nilai koefsien $b_{3}$ sebesar 0,360 nilai ini berarti jika Place naik sebanyak satu persen maka memberikan pengaruh kepada variabel dependen meningkat menjadi 0,360 .

Keempat, untuk nilai koefsien $b_{4}$ sebesar 0,229 nilai ini berarti jika Promotion naik sebanyak satu persen maka memberikan pengaruh kepada variabel dependen meningkat menjadi 0,229.

\section{Uji Hipotesis}

a. Uji $t$

Mengacu pada tabel hasil regresi berganda diatas, maka dapat diperoleh nilai sebagai berikut:

Hasil t-test pertama, pada tabel tersebut diperoleh t-test 2,232 dengan taraf signifikansi 0,029. Hasil ini mengandung arti
Product dapat memberikan dampak signifikan terhadap Keputusan Nasabah karena nilai signifikansi lebih kecil dari 0,05.

Hasil t-test kedua, pada tabel tersebut diperoleh t-test 2,128 dengan taraf signifikansi 0,037. Hasil ini mengandung arti Price dapat memberikan dampak signifikan terhadap Keputusan Nasabah karena nilai signifikansi lebih kecil dari 0,05.

Hasil t-test ketiga pada tabel tersebut diperoleh t-test 3,346 dengan taraf signifikansi 0,001. Hasil ini mengandung arti Place dapat memberikan dampak signifikan terhadap Keputusan Nasabah karena nilai signifikansi lebih kecil dari 0,05.

Hasil t-test keempat, pada tabel tersebut diperoleh t-test 3,106 dengan taraf signifikansi 0,003. Hasil ini mengandung arti Promotion dapat memberikan dampak signifikan terhadap Keputusan Nasabah karena nilai signifikansi lebih kecil dari 0,05. b. Uji $f$

Uji $f$ diaplikasikan untuk mengetahui apakah variabel independen dapat memberikan pengaruh atau tidak secara bersamaan. Berikut hasilnya:

\section{Tabel 2 Hasil Uji F} ANOVA $^{\mathrm{a}}$

\begin{tabular}{|l|r|r|r|r|r|}
\hline Model & $\begin{array}{c}\text { Sum } \\
\text { of } \\
\text { Squar } \\
\text { es }\end{array}$ & df & $\begin{array}{c}\text { Mea } \\
\mathrm{n} \\
\text { Squa } \\
\text { re }\end{array}$ & F & Sig. \\
\hline 1 Regre & 26.14 & 4 & 6.53 & 3.8 & .00 \\
& 8 & 94 & $7^{\mathrm{b}}$ \\
ssion & $\begin{array}{r}100.7 \\
\text { Resid }\end{array}$ & 60 & 1.67 & & \\
ual & 13 & 9 & & \\
Total & $\begin{array}{r}126.8 \\
62\end{array}$ & 64 & & & \\
\hline
\end{tabular}

a. Dependent Variable: y

b. Predictors: (Constant), x4, x3, x2, x1

Mengacu pada hasil uji $f$ yang disajikan diatas, diperoleh hasil $f$-statitics sebesar 3,894 dengan signifikansi 0,007. Hasil ini mengandung arti bawah seluruh variabel 
independen mampu memebikan pengaruh signifikan terhadap keputusan nasabah karena nilai signidikan lebih kecil dari 0,05.

\section{Analisis Koefisien Determinasi}

Uji koefisien determinasi digunakan untuk mengetahui variabel bebas mampu memberikan kontribusi kepada variabel terikat. Berikut hasil pengujiannya:

\section{Tabel 3 Hasil Uji Koefisien Determinasi} Model Summary ${ }^{b}$

\begin{tabular}{|c|c|c|c|c|}
\hline $\begin{array}{c}\text { Mod } \\
\text { el }\end{array}$ & $\mathrm{R}$ & $\begin{array}{c}\mathrm{R} \\
\text { Squar } \\
\mathrm{e}\end{array}$ & $\begin{array}{c}\text { Adjust } \\
\text { ed R } \\
\text { Squar } \\
\mathrm{e}\end{array}$ & $\begin{array}{c}\text { Std. } \\
\text { Error of } \\
\text { the } \\
\text { Estimate }\end{array}$ \\
\hline 1 & $\begin{array}{r}.454 \\
\mathrm{a}\end{array}$ & .206 & .153 & 1.296 \\
\hline
\end{tabular}

a. Predictors: (Constant), x4, x3, x2, $\mathrm{x} 1$

b. Dependent Variable: y

Sesuai dengan tabel yang dihasilkan diatas, terdapat nilai Adjusted R Square ialah 0,153 atau sama dengan $15,3 \%$. Hal ini mengandung arti bahwa kemampuan kontribusi variabel bebas terhadap variabel terikat sebesar $15,3 \%$ sisanya $84,7 \%$ dijelaskan oleh variabel lain.

\section{KESIMPULAN}

Berdasarkan dari hasil analisis data dan pembahasan diatas maka dapat disimpulkan pengaruh dari variabel independen terhadap variabel dependen. Pertama, hasil t-test pertama, diperoleh t-test 2,232 dengan taraf signifikansi 0,029, artinya Product memapu memberikan pengaruh secara signifikan terhadap Keputusan Nasabah Simpanan Fleximax secara parsial.

Kedua, hasil t-test diperoleh t-test 2,128 dengan taraf signifikansi 0,037, aryinya Price mempu memberikan pengaruh secara signifikan terhadap Keputusan Nasabah Simpanan Fleximax secara parsial.

Ketiga, hasil t-test diperoleh t-test 3,346 dengan taraf signifikansi 0,001, artinya Place memapu memberikan pengaruh secara signifikan terhadap Keputusan Nasabah Simpanan Fleximax secara parsial.

Keempat, hasil t-test diperoleh t-test 3,106 dengan taraf signifikansi 0,003. Artinya Promotion memapu memberikan pengaruh secara signifikan terhadap Keputusan Nasabah Simpanan Fleximax secara parsial.

Uji Pengaruh Product, Price, Place Dan Promotion Terhadap Keputusan Nasabah secara simultan diperoleh hasil f-statitics sebesar 3,894 dengan signifikansi 0,007. Hasil ini mengandung arti bawah seluruh variabel independen mampu memberikan pengaruh signifikan terhadap keputusan nasabah karena nilai signidikan lebih kecil dari 0,05.

Implikasi dalam penelitian ini pihak manajemen Bank Panin Dubai Syariah harus bisa mempertahankan dan dapat meningkatkan kembali produk-produk perbankan yang sesuai dengan kebutuhan masyarakat khususnya Simpanan Felximax mampu menjawab kebutuhan masyarakat saat ini. Dengan kemudahan dan keunggulannya. Sehingga banyak nasabah yang tertarik untuk menyimpan dananya dengan produk simpanan fleximax. Dengan memperhatikan faktor-faktor bauran pemasaran, maka hal ini dapat menunjang berjalannya perusahaan dan mampu bersaing dengan produk konvensional yang lebih dulu ada.

\section{DAFTAR PUSTAKA}

Angipora, Marius P. 2002. Dasar-Dasar Pemasaran. Jakarta: PT. Raja Grafindo Persada.

Annurfa, Dyah Ayu, and Aris Sunindyo. 2020. "Analisis Pengaruh Marketing Mix Terhadap Pengambilan Keputusan Nasabah Menabung Pada Bank Jateng Cabang Ungaran." Keuinis: Keuangan dan Bisnis 8(2): 93-105.

Assauri, Sofjan. 1998. Manajemen Produksi. Jakarta: Fakultas Ekonomi Universitas 
Indonesia.

Baskoro, Aji, Leonardo Budi Hasiholan, and Adji Seputra. 2021. "Pengaruh Implementasi Marketing Mix Terhadap Keputusan Nasabah Dalam Memilih Produk Tabungan Bank Danamon (Studi Kasus Pada Nasabah Bank Danamon Citraland Semarang)." Journal of Management 7(1).

Fajar Fahrudin, Muhammad, and Emma Yulianti. 2015. "Pengaruh Promosi, Lokasi, Dan Kualitas Layanan Terhadap Keputusan Pembelian Nasabah Bank Mandiri Surabaya." Journal of Business \& Banking 5(1): 149. https://journal.perbanas.ac.id/index.php/j bb/article/view/478.

Fajri, Detha Alfrian. 2013. "Pengaruh Bauran Pemasaran Jasa Terhadap Keputusan Menabung (Survei Pada Nasabah Bank Muamalat Cabang Malang)." JURNAL ADMINISTRASI BISNIS (JAB) 6(2): 110.

Gitosudarmo, I. 2000. Manajemen Pemasaran Edisi Pertama. Yogyakarta: BPFE.

Ibad, Syamsul, Rois Arifin, and Agus Priyono. 2018. "Pengaruh Bauran Pemasaran Jasa (Product, Price, Place, Promotion, Process, People, and Physical Evidence ) TERHADAP KEPUTUSAN PEMBELIAN." Jurnal ilmu \& Riset MAnajemer 6(10): 167-79.

Indratama, Aditya Bagus, and Yessy Artanti. 2014. "Pengaruh Citra Merek Dan Promosi Penjualan Terhadap Keputusan Nasabah Memilih Tabungan Bank Syariah Mandiri." Jurnal Ilmu Manajemen (JIM) 2(4).

Jalaludin. 2018. "Pengaruh Kualitas Produk Funding Dan Kinerja Karyawan Terhadap Kepuasan Anggota Serta
Impiikasinya Kepada Loyalitas Angggota Studi Kasus Di KPPS BMT Mitra Sadaya Bandung Dan Purwakarta." UIN Sunan Gunung Djati Bandung.

K., Firman Yulianto, and Agung Yuniarinto dan Surachman. 2010. "Analisis Pengaruh Faktor Bauran Pemasaran Terhadap Pertimbangan Nasabah Dalam Memilih Bank Syariah Di Kota Medan.' Jurnal WACANA 13(4): 537-51.

Kartajaya, Hermawan. 2006. Syariah Marketing. Bandung: mizan.

Kasmir. 2004. Manajemen Perbankan. Jakarta: Rajawali Press.

Kondoy, Beatric M . J., Bernhard Tewal, and Frederik Worang3. 2016. "Bauran Pemasaran Dan Pengaruhnya Terhadap Keputusan Menjadi Nasabah Di BPR Prisma Dana Manado." Jurnal EMBA: Jurnal Riset Ekonomi, Manajemen, Bisnis dan Akuntansi 4(4): 1025-36.

Kotler, P, and G Armstrong. 2000. Manajemen Pemasaran, Analisis, Perencanaan, Implementasi, Dan Pengendalian. Jakarta: Erlangga.

Kotler, Philip. 2003. Manajemen Pemasaran Edisi Kesebelas. Jakarta: Gramedia Pustaka Utama.

Kotler, Philip, and K L Keller. 2009. Manajemen Pemasaran. Jakarta: Erlangga.

Kristanto, Antonius Heru. 2013. "Analisis Pengaruh Bauran Pemasaran Terhadap Keputusan Nasabah Dalam Memilih Produk Tabungan Batara Pada Bank BTN Cabang Pontianak." EJVE: Equator Journal Of Management And Entrepreneurship 1(3).

Lupiyoadi, Rambat. 2001. Manajemen Pemasaran Jasa. Jakarta: Salemba Empat.

EKSISBANK (Ekonomi Syariah dan Bisnis Perbankan), Volume 5, Nomor 1, Juni 2021 
Marzuki, Ghozali. 2010. “Analisis Keputusan Nasabah Menabung: Pendekatan Dan Komponen Logistik Studi Pada Bank Syariah Di Malang

- $-\overline{\text { J Journal of }} \overline{\text { Indonesian }}$ Applied Economics 4(1): 43-57.

Paninbanksyariah. 2021. "Profil Perusahan Bank Panin Dubai Syariah." Panin Dubai Syariah Bank.

Panindubaisyariah. 2021. "Simpanan Fleximax." $\quad P T$ Bank Panin Dubai Syariah.

Reality, Tim. 2008. Kamus Terbary Bahasa Indonesia Dilengkapi Ejaan Yang Benar. Jakarta: OT. Reality Publisher.

Sari, Novia, and Alim Murtani. 2020. "Pengaruh Strategi Marketing Terhadap Keputusan Nasabah Menggunakan Produk Tabungan Simpatik (Studi Pada PT . Bank Mandiri Syariah Kantor Cabang Setia Budi Medan).” Jurnal FEB 1(1): 50-61.

Stanton, W J, and Y Lambert. 1994. Prinsip Pemasaran (Terjemah) Jilid 1. Jakarta: Erlangga.

Supriyono, Kuat. 2014. "Pengaruh Produk, Harga Dan Promosi Terhadap Keputusan Konsumen Dalam Membeli Rumah Pada Perumahan Bukit Semarang Baru (BSB) City Di Semarang." jurnal Skripsi Ekonomi Manajemen: 1-16.

Sutrisna. 2003. Perilaku Konsumen Dan Komunikasi Pemasaran. Bandung: PT. Remaja Rosdakarya.

Syafirah. 2019. "Analisis Profitabilitas PT. BANK BRI Syariah Periode 2009-2018 (Dilihat Dari Pengaruh Financing To Deposit Ratio Dan Non Performing Financing Terhadap Return On Asset)." Eksisbank 3(2): 119-30.
Tasruddin, Ramsiah. 2015. "Strategi Promosi Periklanan Yang Efektif." Strategi promosi periklanan yang efektif 2(1): $107-16$.

Tjiptono, F. 2002. Strategi Pemasaran Edisi Kedua Cetakan Keenam. Yogyakarta: Andi Offset.

Uatma, Chandra. 2009. "Pengenalan Produk Dan Akad Dalam Perbankan Syariah." Bina Ekonomi Majalah Ilmiah Fakultas Ekonomi Unpar 12(2): 42-51.

Wijaya, Evelyn, and Puspa Marantika Ariyani. 2018. "Pengaruh Service Marketing Mix Terhadap Keputusan Nasabah Untuk Menabung Pada PT. Bank Mayapada Internasional TBK Cabang A.Yani Pekanbaru." COSTING: Journal of Economic, Bussines and Accounting 1(2).

EKSISBANK (Ekonomi Syariah dan Bisnis Perbankan), Volume 5, Nomor 1, Juni 2021 http://journal.sties-purwakarta.ac.id/index.php/EKSISBANK/ 